\title{
The neoliberal university, social work and personalised care for older adults
}

\author{
Malcolm Carey* (D) \\ Faculty of Health and Social Care, University of Chester, Warrington, UK \\ ${ }^{\star}$ Corresponding author. Email: m.carey@chester.ac.uk
}

(Accepted 8 December 2020; first published online 11 January 2021)

\begin{abstract}
This article critically examines the impact of the neoliberal university upon social work education, research and practice relating to older people. The article appraises market-led pedagogical reforms, including of the training of social workers who go on to work with older adults, such as in support of policies including personalisation. Influence is drawn from the work of Nancy Fraser: specifically, her understanding of 'progressive neoliberalism', or the improbable fusion of free market ideals with the politics of recognition to create a rejuvenated hegemonic bloc. This theoretical framework is utilised to analyse the prevalence of emancipatory constructs such as empowerment, participation, anti-oppression, equality, choice and independence within the acutely underfunded, bureaucratic and risk-averse fields of social care and social work. While benefiting some older 'service users', it is argued that personalisation policy regularly disadvantages or excludes older people within fragmented adult social care sectors. Progressive neoliberalism has helped to promote supplyled training and policies which envisage participative and asset-based self-care whilst more often excluding or objectifying older adults, especially those with higher-level needs.
\end{abstract}

Keywords: neoliberal university; personalisation; social work; progressive neoliberalism; ageing

\section{Introduction}

In recent years, universities and other higher education institutions (HEIs) have been encouraged to integrate much more with the principles and economic practices of neoliberalism. Among other reforms, this has included the adoption of greater marketisation, commercialisation, business-style managerial practices, as well as much more competition and enterprise encouraged between scholars, institutions and other 'service providers'. The performance of academics is now more readily scrutinised, in addition to an often meticulous focus placed on auditing, metrics, research impact and league tables, as well as closer links forged between universities and big business, local employers and other stakeholders (Berg et al., 2016; Eagleton, 2018; Acker and Wagner, 2019). These ideological trends have frequently led to 'blurred 
lines' forming between 'profit seeking and knowledge seeking pursuits' (Lund, 2020: 466), while pedagogues and students are encouraged to 'move one step closer to the values of global neoliberal capitalism' (Hayes and Jandrić, 2014: 195). For Ball (2015: 258-261), in areas such as research, a common outcome for most pedagogues has included the everyday experience of being viewed through objectifying categories:

Once in the thrall of the index, we are easily reduced by it to a category or quotient - our worth, our humanity and complexity are abridged. We come to 'know' and value others by their outputs rather than their individuality and humanity. Those who 'under-perform' are subject to moral approbation. (Ball, 2015: 258)

Alongside other welfare professions based in HEI settings, social work has been urged to actively embrace integrated systems of quasi-market-based care (Harris, 2003; Webb, 2006; Petrie, 2015). Within education, reforms in countries such as the United Kingdom (UK) have included the development of partnerships and apprenticeships with local authorities, who increasingly take a lead in funding education programmes, as well as having a role in deciding course content. Relatedly, course programmes have continued to become more skills and performancelearning focused, and less reliant on theory-based analysis or critique (Jones, 1996; Orme, 2012; Fenton, 2019). Despite representing the fastest growing and largest 'service user' group, attention given to older people on generic social work programmes within the neoliberal university has remained minimal (Gwilym, 2018; Geyer and Louw, 2020). As with other 'service user' groups, including children or families, focus upon direct work with older adults has also narrowed, with most attention now given to safeguarding and risk-averse work with the 'oldest old' or fourth-agers (Webb, 2006; Dustin, 2007; Lymbery and Postle, 2010; Carey, 2016).

This article seeks to examine a largely overlooked aspect of the neoliberal university, that of its influence upon social work education and policy relating to ageing. It analyses reforms which have influenced the narrowing of research and training of social workers, especially those who go on to work with older people. This includes the influence of seemingly progressive concepts that can include 'service user' participation, empowerment, autonomy, inclusion, anti-oppression and independence, within ever-more quasi-customer yet risk-averse fields of social care and social work. As case example, the ongoing marketisation of social care is considered in relation to the consumer-driven policy of personalisation for older people, itself a key part of training and later practice for adult social workers in the UK as elsewhere. This is discussed as personalisation offers a good case example of the widening gap between seemingly progressive rhetoric generated as part of social work education in the neoliberal university, and the often very different realities confronted at 'street-level' by qualified adult social workers providing limited market-based social care for community-based older adults. Indeed, although offering benefits to some, it is argued that this policy within adult care largely marginalises, stigmatises or excludes older service users. The analysis draws influence from Fraser's (2019) concept of 'progressive neoliberalism', in which a pro-market ideological drive has accommodated elements of progressive ideals such as equality, social justice and inclusion. Such trends have led to the forming of a revitalised 'hegemonic bloc' which universities play an important role supporting. 


\section{The neoliberal university and progressive neoliberalism}

Traditionally at least, universities and HEIs have retained a largely positive public image, encapsulated by a pedagogical culture which endorses open learning and theoretically informed democratic debate; as well as innovative research and free thinking, set alongside a tendency to encourage moral and social enlightenment. Idealistic or not, this reputation can appear as somewhat remote within the confines of the market-driven, neoliberal or 'corporate university'. Several studies, for example, have highlighted how scholarship and pedagogy are increasingly corrupted by the commodification of learning within ever-more business-orientated teaching and research sectors (Ball, 2012, 2015). This has included the growth of an administrative and surveillance-heavy culture that prioritises targets, bureaucracy, monitoring, short-term goals and the casualisation of employment, which have led to a burgeoning class of precariat academics, researchers and other staff (Berg et al., 2016; Curtis, 2016). Fierce competition between institutions, academics and researchers can also reinforce traditional forms of inequality and exclusion based on age, class, gender and ethnicity, among other categories (Deem et al., 2005; Granleese and Sayer, 2006; Acker and Wagner, 2019; Lund, 2020; Wellcome Trust, 2020).

For some at least, the relatively swift adoption of market and business principles and practices in sectors such as universities has been supported by a unique hegemonic driver. For example, Nancy Fraser (2019) has highlighted the emergence and wider social and political influence of what she terms 'progressive neoliberalism'. This ideological endeavour includes the eclipse of material redistribution by recognition, in tandem with a political-economic project that can engage 'with several different and even competing projects of recognition-including progressive ones' (Fraser, 2019: 12-14). According to Fraser (2019), a dynamic and evolving discourse of neoliberalism has actively engaged with yet adapted progressive ideals, including those drawn from feminism, multiculturalism, environmentalism, age, disability, gay and transsexual-related rights, among others. This includes greater recognition being given rhetorically and, in part through policy mandates, to otherwise excluded or disenfranchised social groups. Through often calculated attention given to identity and recognition-related issues, financially driven neoliberalism has merged with progressivism to develop a 'hegemonic bloc' in Gramsci's (1971) understanding, or dominant ruling alliance based around ideas, social relations and institutions. Social order and consent among the wider population has been strengthened for ruling elites through the partial acceptance and promotion of progressive political ideals and concepts which previously would have been confined to 'identity politics' supported by minority groups. However, according to Fraser, this restricted integration of progressive ideals to reset the neoliberal hegemonic bloc with new leftist constructs has ultimately been used to extend the free market further:

Determined to unshackle market forces from the heavy hand of the state and the millstone of 'tax and spend', the classes that led this bloc aimed to liberalize and globalize the capitalist economy. What this meant, in reality, was financialization: dismantling barriers to, and protections from, the free movement of capital; deregulating banking and ballooning predatory debt; deindustrializing; weakening 
unions; and spreading precarious, badly paid work ... Only when decked out as progressive could a deeply regressive political economy become the dynamic centre of a new hegemonic bloc. (Fraser, 2019: 12-14)

Progressive discourses from civil society were raided by political elites and subsequently repackaged ideologically through government, institutional and professional narratives to become 'superficially egalitarian and emancipatory' (Fraser, 2019: 13). As a structurally embedded, universal and socially influential yet disparate set of institutions, HEIs and universities have played an important role as part of this market-based hegemonic bloc. Once radical yet ultimately marginalised concepts such as equality, social justice, participation or anti-discrimination have been actively adopted by university sectors and welfare professional groups. This is despite each often being rebranded and diluted into more politically amenable and conservative forms. Recent examples within academic and policy discourses include those built around inclusion, participation, anti-oppression, empowerment, wellbeing and equality. Such constructs may mask or conceal different agendas, outcomes or projects, which might include new forms of age-related inequality or social exclusion in community-based settings.

Participation narratives, for example, regularly maintain a positive image that promotes democratic engagement, empowerment and inclusion for service users such as older adults, who, within Fordist welfare systems, were previously ignored (Cowden and Singh, 2007; Brett et al., 2010; Hafford-Letchford and Formosa, 2016). Nevertheless, through the ideological prism of progressive neoliberalism, user involvement or related public consultation exercises can be used as social technologies of legitimation to achieve other agendas. Such ideological schemes have included the aggressive expansion of markets and private-sector provisions within health and social care since the 1980s, alongside welfare professional behavioural interventions disseminated through a participation hegemony which promotes active citizenship and responsible subjects (Clarke, 2004; Levitas, 2005; Kemshall, 2010; Fenwick and McMillan, 2012). For example, patient involvement and participation in decision-making has been ever present as part of 'liberal' professional and research community narratives and documentation within institutions such as the National Health Service (NHS). Nevertheless, evidence suggests that staff still tend to control most staff-stakeholder interactions or core decision-making in activities such as care provision or research, and older people can be susceptible to institutionally based control (Gilleard and Higgs, 2000; Levitas, 2005; Fenwick and McMillan, 2012). Among others, Fenwick and McMillan (2012), Scott-Samuel and Smith (2015) and Daly and Westwood (2018) note the popularity of costsaving policy packages such as those built around participation or asset-based care by neoliberal governments, alongside their relative appeal to welfare professions or local government officials. Despite popularity, such policy initiatives are rarely able to confront significant power differences, reverse material inequality or reduce any structured dependency experienced by older people. Indeed, they may ironically extend each by helping to justify further professional powers or policies which intensify types of age-related exclusion.

Another distinguishing trait of the neoliberal university remains its capacity to focus upon presenting a positive image. This can include drawing influence from 
the practices of big business and marketing on how to present or market its services and products to potential consumers (Ball, 2012; Morrissey, 2015; Acker and Wagner, 2019). This may, for example, influence how professional training, practices or policy-orientated research is constituted and presented. A central part of social work education and later practice, for example, remains its commitment to anti-discriminatory and anti-oppressive practice. Alongside a socially just understanding of the impact of priority forms of exclusion such as racism, sexism or disablism, social workers are expected to provide at least some evidence that they are committed to fighting ageism in all its different forms (McLaughlin, 2005; Baines, 2016). Among others, McLaughlin (2005) has expressed significant doubts about the sincerity of these altruistic claims. Far from challenging the oppression of social excluded groups, McLaughlin instead argues that anti-oppressive training for social workers remains politically detached from its radical origins of the 1960s and 1970s, serves professional interests, and has become institutionalised within universities and practice settings, so as to allow the state 'to reposition itself once again as the benign provider of welfare' (McLaughlin, 2005: 283, 300). Moreover, through an essentially liberal-humanist discourse that dematerialises inequality, pedagogues morally condition students on themes such as the importance of using appropriate non-discriminatory language rather than highlighting structural forms of exclusion or poverty. Subsequently, in later casework-orientated praxis the role of any macrostructurally determined influences of society can be lost and oppression is instead identified as being 'due to the moral failings of service users who need censure and correction from the anti-oppressive social worker' (McLaughlin, 2005: 283, 300). Other theorists have highlighted the utilisation of pervasive consumer-based constructs including empowerment, asset-based care and participation to instil a micro-disciplinary ethic of self-help, personal responsibility and resilience for older citizens, including to discourage reliance upon ever-diminishing formal welfare state provisions (Gilleard and Higgs, 2000; Powell, 2012; Rose and Abi-Rached, 2013; Daly and Westwood, 2018).

\section{Neoliberal social work, education and older people}

Since the 1980s, neoliberal-inspired social work and social care have expanded throughout the UK, and in many other European countries, as elsewhere, such as in Canada, Australia and parts of South America (Ferguson et al., 2005; Grassi and Alayon, 2005). The formation of quasi-markets of health and social care has encouraged an enduring reduction of direct state support, alongside the rapid growth of private- (and initially some voluntary) sector provisions including residential, nursing and domiciliary social care (Lymbery, 2010). A discourse built around a narrative of market-infused constructs has flourished, and included precedence given to autonomy, choice, purchaser/provider splits, wellbeing, stakeholder participation, user empowerment, performance, among other examples (Clarke, 2004; Jordan and Drakeford, 2012; Baines, 2016). Within a rapidly expanding yet often poorly funded and fragmented 'social work business', contact between older 'service users' and 'care managers' became formal and brief, with focus built around the rationing of finite resources and the bureaucratic monitoring of eligibility for support (Harris, 2003: 41-46; Ferguson, 2007; Lymbery and Postle, 2010). 
Provision within social care now chiefly targets the quantification of potential risks among 'fourth agers', meeting higher-level health care-related needs, or providing limited physical care or partially responding to safeguarding concerns (Dustin, 2007; Means, 2012; Hall and Scragg, 2012). In England, core legislation such as the NHS and Community Care Act 1990, and more recently the Health and Social Care Act 2012 and Care Act 2014, have further normalised competition, rationing and privatisation within social care (Glynos et al., 2015: 63-64). In practice, a progressive market hegemony has fused with other professional and pedagogical narratives - including geriatric medicine and traditional forms of social work - to construct a compelling and seemingly legitimate risk-averse discourse. Despite the profuse language of empowerment, wellbeing, equality and antioppression, older people are often interpreted through bureaucratic health and social care classification systems and risk-averse discourses as representing a cost, threat or burden (Tomkow, 2018).

Although market-led reforms and 'austerity' programmes have restricted much purposeful social work provision during the past three decades, the marginalisation of social work with older people has a much longer history. Despite representing the fasting growing user group, studies of social work practice have often supported a view of older people as a low priority or nuisance. This includes a commonplace professional view that real social work takes place with children and families, and that older people should be reserved for the attention of unqualified staff or volunteers (Phillipson, 1982: 104; Hall and Scragg, 2012). Geyer and Louw's (2020: 93) recent survey-based research with 395 social work students notes that common reasons given for the limited interest in working with older people includes ageism; inadequate knowledge about later-stage ageing; assumptions that work with children is much more complex, meaningful and rewarding; and that working with older people is assumed to be 'not challenging or rewarding'. Other studies have noted that social work students can assume that communication with older people is likely to be difficult; or that apparently commonplace problems such as poverty, loneliness, frailty or a lack of support provided will provoke either depression or feelings of guilt (Phillipson, 1982; Hall and Scragg, 2012; Geyer and Louw, 2020). Despite this, all students on taught programmes in universities (and which supply most qualified social workers in the UK) will have an option to specialise in work with older people, and much generic taught material is still intended to be valid for all 'service user' groups.

As part of an eagerness to regulate social work education and practice - and more generally reduce welfare provision through policy and law-Gwilym (2018) argues that the Coalition and Conservative governments in the UK have since 2010 neglected areas such as gerontological social work. Focus through 'protectionist language' has instead been given to safeguarding among children in need of care, and it is here that the real drive for raising standards will take place reflecting political and media imperatives about this highly visible field' (Gwilym, 2018: 410). Within social work education itself, related reforms have included much longer periods of time spent on practice placements and less time given to study or teaching on campus. Moreover, course content relating to sociology, social policy or critical psychology has been significantly reduced as part of more standardised taught curriculums (Jones, 1996). These reforms have occurred alongside the elevation of 
technical, competency, capability and skills-based training: all of which seemingly help to develop practitioners who will 'not ask "difficult" questions, and therefore are easier for managers to manipulate and control' (Morely, 2019: 438). Central to these changes is the influence of employers and related government policy, including ongoing reforms within and of university sectors (Jones, 1996; Harris, 2003; Morely et al., 2017, 2019). For example, in the UK since the 1970s, governments and the now defunct Central Council on Education and Training in Social Work argued for much closer partnerships between universities and local authority employers. Since then, employers' influence and direct control has grown significantly, including to a point where they now increasingly fund and lead universitybased social work training. Such reforms have, nevertheless, often faced criticism. Partnerships, for example, are viewed as being much more about instilling student compliance to procedure, the law and government policy, including by encouraging social workers to accept the principle of a market-driven society and related inequalities (Dominelli, 1997; Orme, 2012; Morley et al., 2017). Morley et al. (2019: 141-149) argue that 'technicist education' within social work now prioritises 'repetitive, linear and formulaic' training for practice, which is dominated by audits, form-filling, and the careful control of finances and narrowly focused casework.

A cultural shift has also taken place, with numerous empirical studies suggesting that many social work students and younger practitioners now fail to acknowledge the impact of structural factors upon service users. Indeed, many seem to instead accept the validity of 'hegemonic practices focused on behaviour, protection and risk assessment rather than help, welfare and advocacy' (Fenton, 2019: 451). Davies and Leonard add further political context when they conclude that as an aspiring profession keen to impress neoliberal governments, social work endeavours to prove it is capable of embracing scientific knowledge and technical skills, so as to play 'an important role in the monitoring and control of problematic populations' (Davies and Leonard, 2005: x). Subsequently, much greater focus in education, research, training and practice is now placed upon paradigms and methodologies that fit closer to minimalist risk-averse policies or interventions. Notable examples include behavioural psychology, attachment theory, biomedical perspectives, functionalist sociology, systems theory and related models of practice, evidence-based perspectives, and so on.

Overuse of any such reductive paradigms have nevertheless faced criticism. For example, Estes et al. (2003) note how an ongoing obsession with scientific objectivity in welfare professional roles will often limit any grasp of complex historical explanations or other perspectives for older people. This can depoliticise professional narratives whilst buttressing economic ideals such as rational choice (usually presented as autonomy within professional ethics), efficiency or performance, and allow complex events to be 'colonized by exclusively professional understandings of adult ageing' (Estes et al., 2003: 79-80). Overreliance upon biomedical or healthcare research into dementia can also promote a specific focus upon randomised trials, quantitative methodologies or service evaluations, with the social complexity or human impact of a chronic condition which counters essentialist analysis becoming discursively marginalised. Some of these trends have been shared across associate welfare 'helping professions' (Estes et al., 2003: 80-81, 95). Tomkow (2018: 695-699), for example, draws from Foucault's concept of biopower to argue that in the UK frailty 
now represents an omnipresent 'truth discourse' which is embedded in biomedical knowledge, professional training and clinical praxis. Within medicine and health care this helps to fortify the professional control of older people, and further augments an ever-more dominant political narrative that the growing ageing population represents 'an economic threat to the current configuration of health care in the UK' (Tomkow, 2018). Discursive attention is again drawn away from the impact of market-driven structural inequalities and instead moves towards responsibilities which are to be managed by older people or their families (Tomkow, 2018: 695-699).

\section{Personalisation and older people}

Few policies within formal care embody the political contradictions and tensions embedded in permissive neoliberalism more than personalisation for older adults. Training for social workers in the UK, as elsewhere, has for some time included a strong emphasis placed upon personalisation, person-centred care and associate initiatives including participation and asset-based care. However, the role of adult social workers was originally intended to be minimal due to assumptions that older adults could join younger disabled people and lead what was politically envisaged as the archetypical consumer-based model of self-directed care (Lymbery, 2014). Strong emphasis, for example, was placed upon service userdefined needs and self-organised care rather than developing professional roles in determining assessments of need or care provided. Markets of care, rational choice, autonomy and empowerment were intended also to replace the symbiotic role of local authorities and welfare professionals as seemingly remote institutions and faceless gatekeeping mandarins who served their own professional interests whilst promoting dependency among clients (Social Care Institute for Excellence (SCIE), 2012; West, 2013; Woolham and Benton, 2013).

Personalisation policy has been supported by consecutive Labour, Coalition and Conservative governments within the UK, and first emerged in England in 2005. The policy pledged that independent living, person-centred planning and selfdirected support - such as with personal budgets, direct payments, and associated information or advice if required - would replace any previous 'one-size-fits-all' universal social care provision. Relevant guidelines claimed to offer more independence, flexibility, choice and control for empowered community-based service users who required social care support, and this included more opportunities to engage with activities such as leisure (SCIE, 2012). For example, at the time of writing, on the government-funded SCIE's Social Care Online website there remains a publication entitled Personalisation: An Easy Read Guide (SCIE, 2012). This 20-page summary includes 48 pictures of smiling and laughing disabled and older people engaged in a variety of social activities which include active learning, the playing of games, drinking of wine, group walking, and so on. Alongside positive imagery the summary details how personalisation will reify service users to 'engage more socially', 'travel around', 'learn new things' and 'have fun' (SCIE, 2012: 3-15).

Although emphasis was initially placed on users 'having a say' about 'the services which would work best for them' (Gray and Birrell, 2013: 80-81), scarce financial resources quickly meant that focus was instead built around more traditional means-tested services such as domiciliary, day and residential care provision 
(Means, 2012; Lymbery, 2014). The document Putting People First had earlier highlighted the apparent strains of a rapidly ageing population, the growth of more complex communities and stressed a pressing need to 'explore options for the longterm funding of the care and support system' (Department of Health, 2007: 2-5). As with subsequent legislation and policy, including the Care Act 2014, use of progressive terminology and slogans drawn from disability rights campaigns were presented within care-related institutions and publications. Putting People First, for example, argued that staff were to be involved 'in the cutting edge of innovation', and older people represented 'participants in the change program' and were pivotal to 'engagement', 'choice' and a 'shared commitment to social justice'. Similarly, the Care Act 2014 has emphasised the importance of 'maximizing personal choice' and 'person-centred planning' for older users, and highlights that support 'should be holistic and empowering' (Barnes et al., 2017: 176-180). In contrast to earlier legislation, the Care Act has also given more attention to encouraging service users, unpaid carers, family members and wider community groups, to draw actively from their 'assets' and 'participate' more in supporting themselves. Professionals such as social workers, health and other care workers are encouraged to inspire selfdirected, 'asset-based' or 'strengths-based' support.

Numerous critics have continued to highlight the prevalence of more consistent political themes which challenge the cross-party development of personalisation. For example, on behalf of Age UK, Feltoe and Orellana (2013) draw from a wide range of empirical studies to evaluate the impact of personal budgets as part of personalisation policy for older people in receipt of social care support. While they accept the potential of personalised care to improve support for older adults, numerous gaps and inconsistencies regarding overall provision are highlighted. This includes often alarming differences of support available geographically and among specific user groups. Overall, personal budgets also appear to be failing to meet many of the needs of older adults:

Older people are more likely to report personal budgets as making no difference to the outcomes they achieve; and less likely to report improvements in outcomes concerned with a greater sense of control, improved social contracts and community engagement. To this end personal budgets are failing to deliver the benefits to older people which younger disabled people are able to achieve. (Feltoe and Orellana, 2013: 10)

It is also noted that if eligible for support, personalised care and payments can be difficult for many older people to manage, and may, ironically, make users more emotionally or physically dependent on their family or other carers. Evidence has also stressed the inequalities which can emerge around mental capacity, or physical or psychological frailty, especially if support from family or friends is not readily available (Glendinning et al., 2008). Moreover, if able to access finite personalised care, most older people are much more likely subsequently to face an unexpected deterioration in health or other crisis. Therefore, an expectation of organising care with limited support is either largely unattainable or will represent either a significant challenge or risk. In addition, personalisation and self-directed care will not untypically privilege more educated families (Ferguson, 2007; Woolham and Benton, 2013). 
Evidence also suggests that personalisation can fortify traditional ageist assumptions, not least by local authorities placed in charge of assessments and eligibility to receive care or not. In Feltoe and Orellana's (2013) appraisal of studies, priority had often been given to younger disabled adults, with insufficient information made available to older people. Service users who were frail, required 'end-of-life' care or who had conditions such as dementia were regularly excluded from the option of personalised care, despite these groups more often representing the people most likely to meet higher eligibility criteria to receive funding towards providing health or social care provision. Despite its popularity with governments and professional groups, this brings into question the feasibility of the policy for most older people likely to be eligible. For older adults, rather than younger people, there were also far fewer resources made available, and greater emphasis was placed on providing personal care rather than endorsing the use of social or leisure activities.

Within many studies budget restrictions due to austerity policies pursued within the UK since 2008 had severely limited available resources and options to finance social care support. Rabiee et al. (2016) drew from interviews with 34 social care staff across three local authorities in England and discovered that most older people receiving domiciliary care preferred not to manage their own support, and tended instead to allow a local authority or service provider to manage both their budget and care. Choice and control were severely restricted or not evident for older people, which was further compromised by 'resource constraints, new communication barriers, restrictions on the use of managed personal budgets and inadequate training for practitioners' (Rabiee et al., 2016: 464-467). Brooks et al. (2017) interviewed 'personalisation lead officers' for older and disabled people across 16 adult social care departments in two authorities in England. The authors examined personalised support for informal carers and service users yet highlighted 'fragmented and inconsistent' practices on behalf of local authorities (Brooks et al., 2017: 152-162).

As an early critic, Ferguson (2007) argued that personalisation policy maintained a strong association with New Labour's repeated use of 'warmly persuasive words': notably highlighting 'empowerment' and 'partnership' as key ideological terms used to extend market-driven welfare reforms. As well as expanding use of the core market values of individualisation and autonomy, personalisation has also increased responsibility on behalf of service users, and developed further 'the privatisation of risk' from the state to older people and their families. Further reforms have included the deskilling and further marginalisation of any positive social work role and denial of the influence of poverty and inequality upon user groups or carers working with adults (Ferguson, 2007: 388-397). Ferguson also highlights the political use of personalisation policy to again expand business opportunities for the private sector. For example, call centres for social work in England and Australia have expanded as part of the personalised care policy, with British Telecom in the UK notably benefiting from much greater involvement in social care provision than before. Such call centres, however, can mean that service users have no direct contact with social workers, and they can be used to prompt older people or their carers to seek help elsewhere.

When drawing upon interviews with 50 adults and older people with fluctuating support needs and/or experiencing a deterioration of health, Rabiee (2013) again 
highlights the not uncommon complexities of choice and independence for service users. The research highlighted the 'multi-dimensional nature' of the concept of independence, including that independence tends to be contextually variable, and that the relationship between choice and independence for older and disabled people is 'not always as simple and linear as choice policies assume' (Rabiee, 2013: 881-885). Sothall et al. (2021) draw from data gathered as part of two $\mathrm{PhD}$ studies into the experiences of adult social workers based in the North-East of England. Echoing numerous other studies, they acknowledge the potential of personalisation to promote independence, and recognise some users who had benefited from such new practices, but numerous challenges were again central to their critical findings and analysis. This included the 'liminal space' negotiated by practitioners stood between an idealised consumer-based policy and numerous 'structural barriers' faced by both users and practitioners (Sothall et al., 2021). Briefly, they conclude that the consumer-model of personalised care significantly understates the diverse needs and precarious circumstances often experienced by most community-based older adult users (including safeguarding related), as well as the enduring paradox of any relative dependence on others to make the policy work.

\section{Conclusion}

In The Postmodern Condition, Lyotard (1984) argued that higher education was being dominated by relentless political pressures to improve performance and efficiencies. This included the skills required by students and staff to enhance efficiencies within a rapidly expanding consumer economy and wider society. Often this led to other pedagogical or moral concerns becoming marginalised, and as Marcuse (1964) had earlier suggested, excess political priority was subsequently being given to the administrative and managerial control of markets. These political trends ultimately led to greater powers of influence being held by political elites who were more able to secure their interests and any associated financial benefits. More recently, other authors have proposed that the 'corporate university' now seeks to not only prioritise and extend markets within the economy, but also shape student and staff identities into types 'of competitive, selfinterested individualism that celebrate selfishness, profit-making, and greed' (Giroux, 2008: 142; Eagleton, 2018). As part of a pedagogical business and output model of research relating to ageing and care, institutional focus can now often be built around where grant income is more readily available, with subsequent bias placed on disciplines such as health care, medicine or economics, including specific generously financed areas within health and social care such as dementia care, health economics or physical falls. Consequently, partiality relating to projects and outputs can emerge around funded or financially motivated research themes, with limited value not uncommonly assigned to how results are achieved. This can lead to a perceived loss of research quality, with 'corners being cut and outputs becoming increasingly superficial' (Wellcome Trust, 2020: 3-16). Numerous other aspects of ageing, however significant, can be neglected, with examples including research relating to poverty, inequality, housing or key aspects of social care (Estes et al., 2003; Webb, 2006; Ward and Campbell, 2013). 
More recently, these wider market-based trends can, in part, be contextualised by a proposed adoption of progressive constructs drawn from social movements and minority groups, some of which have been used symbolically to inculcate the language of equality or social justice to validate the expansion of markets. This intimates that university sectors and other HEIs are now part of a revitalised hegemonic bloc, or ruling alliance founded upon shared beliefs, social relations and institutions which weld together 'an expropriative, plutocratic economic programme with a liberalmeritocratic politics of recognition' (Fraser, 2019: 11-12). Earlier, Gramsci (1971: 60-61, 434-436) highlighted how in constructing any 'hegemonic bloc', ruling elites can seek to appropriate selectively ideas and cultural traditions drawn from subjugated 'kindred groups' so as to instate leadership and forms of domination.

Social work for older people within the neoliberal university and related training and policy is now motivated ever more by a narrow focus given to honing skills, functional capabilities and political compliance, more often leading to the selective management of risks or frailty experienced by fourth-agers. Typically, this takes place in business-orientated social care markets which are significantly underfunded, fragmented and infrastructurally weak. It has been argued that constricted learning and knowledge production have expanded, with priority being given to reductive science-based paradigms alongside realist or evidence-based research, which each engender minimal interventions and seek to promote self, family or community based-support for the aged-other. While such outcomes may be contested or resisted at the level of active agency, they are still more likely to reinforce implicitly or otherwise interpretations of later-stage ageing as representing dependence, financial liability, a burden or threat. These reforms often carry important ageist overtones, including by being more likely to marginalise and pathologise older people, ignore or denounce structural and political constraints upon laterstage ageing, and integrate risk-averse narratives, biomedical perspectives and other viewpoints which fit closer with neoliberal and market-led agendas. Current priority given to children and safeguarding above the relative needs of older people in UK policy, and during the training and later practices of social workers, appears to again reinforce these ideologically driven ageist principles.

Through key narratives of the neoliberal university and personalisation which includes a merger of market and humanist concepts such as choice, freedom, co-production, autonomy, strengths, anti-oppression or assets-based care, a progressive reality of sorts can be projected, fortified by the active engagement of students, welfare professionals or users themselves (Althusser, 1971; Butler, 1998; Powell, 2012). Alongside other key UK policies within adult social and health care, such as care management and asset-based care, personalisation has increased professional gatekeeping powers and control, including with discursive precedence given to assessments of need, eligibility for care, brokerage, and so on. Moreover, when applied at street-level, the policy narrative of personal budgets can articulate an instrumental approach to care that induces a crude binary which categorises between positive capacity for self-support and an often stigmatised reliance upon paternalistic care (e.g. Gilbert and Powell, 2012; Barnes et al., 2017). Via a more materialist lens, others add that within a neoliberal hegemony groups such as older 'service users' are not so much duped by anti-representative constructs, but are instead more readily disregarded as 'deficient consumers', labelled as 
overdependent on welfare and subsequently neglected or abandoned by the neoliberal state (Jameson, 1991; Bauman, 1998; Jones and Novak, 1999; Ferguson, 2007; Walker, 2018; Schram, 2019). In discussing social work's almost passive adoption of neoliberalism, Schram (2019: 21) argues that beyond often contrived altruistic words, social workers are now encouraged to instil in service users a belief that they can only achieve their wellbeing 'via the market and must rely on market logic as much as possible to make the economically right choices in all areas of their lives'. An increasingly key part of this hegemonic identity is now ever-more built and disseminated in different discursive forms from within the confines of the neoliberal university.

\section{References}

Acker S and Wagner A (2019) Feminist scholars working around the neoliberal university. Gender and Education 31, 62-81.

Althusser L (1971) Essays on Ideology. London: Verso.

Baines D (2016) Care, austerity and resistance. In Williams C (ed.), Social Work and the City. Basingstoke, UK: Palgrave Macmillan, pp. 193-214.

Ball S (2012) Performity, commodification and commitment: an I-Spy guide to the neo-liberal university. British Journal of Education Studies 60, 17-28.

Ball S (2015) Living the neo-liberal university. European Journal of Education 503, 258-262.

Barnes D, Boland B, Linhart K and Wilson K (2017) Personalisation and social care assessment. British Journal of Psychology Bulletin 41, 176-180.

Bauman Z (1998) Work, Consumerism and the New Poor. Buckingham, UK: Open University Press.

Berg L, Huijbens EH and Larsen HG (2016) Producing anxiety in the neoliberal university. The Canadian Geographer 60, 168-180.

Brett J, Staniszewska S, Mockford C, Seers K, Herron-Marx S and Bayliss H (2010) A Systematic Review of the Conceptualization, Measurement, Impact and Outcomes of Patients and Public Involvement in Health and Social Care Research. London: Clinical Research Collaboration.

Brooks J, Mitchell W and Glendinning C (2017) Personalisation, personal budgets and family carers. Whose assessment? Whose budget? Journal of Social Work 17, 147-166.

Butler J (1998) The Psychic Act of Power: Theories in Subjection. Stanford, CA: Stanford University Press.

Carey M (2016) Journey's end? From residual service to newer forms of pathology, risk aversion and abandonment in social work with older people. Journal of Social Work 16, 344-361.

Clarke J (2004) Dissolving the public realm? The logics and limits of neo-liberalism. Journal of Social Policy 33, 27-48.

Cowden S and Singh G (2007) The 'user': friend, foe or fetish? A critical exploration of user involvement in health and social care. Critical Social Policy 27, 5-23.

Curtis B (2016) The performance-based research fund, gender and a cultural cringe. Globalisation, Societies and Education 14, 87-109.

Daly M and Westwood S (2018) Asset-based approaches, older people and social care: an analysis and critique. Ageing \& Society 38, 1087-1099.

Davies L and Leonard P (eds) (2005) Social Work in a Corporate Era. London: Routledge.

Deem R, Morley L and Tlili A (2005) Negotiating Equity in Higher Education Institutions. London: Higher Education Funding Council for England.

Department of Health (2007) Putting People First: A Shared Vision and Commitment to the Transformation of Adult Social Care. London: Department of Health.

Dominelli L (1997) Sociology for Social Work. Basingstoke, UK: Macmillan.

Dustin D (2007) The McDonaldisation of Social Work. Farnham, UK: Ashgate.

Eagleton T (2018) Culture. New Haven, CT: Yale University Press.

Estes CL, Biggs S and Phillipson C (2003) Social Theory, Social Policy and Ageing: A Critical Introduction. Maidenhead, UK: Open University Press.

Feltoe E and Orellana K (2013) Making Managed Personal Budgets Work for Older People. London: Age UK. 
Fenton J (2019) Social work education and the challenge of neoliberal hegemony. In Webb SA (ed.), The Routledge Handbook of Critical Social Work. London: Routledge, pp. 449-461.

Fenwick J and McMillan J (2012) Public participation and public service modernisation: learning from New Labour? International Journal of Public Administration 35, 367-376.

Ferguson I (2007) Increasing user choice or privitizing risk? The antimonies of personalisation. British Journal of Social Work 37, 387-403.

Ferguson I, Lavalette M and Whitmore E (2005) Globalisation, Global Justice and Social Work. Abingdon, UK: Taylor \& Francis.

Fraser N (2019) The Old Is Dying and the New Cannot Be Born. London: Verso.

Geyer S and Louw L (2020) Generation Z undergraduate social work students' knowledge of and attitudes towards older persons: implications for professional training. Journal of Gerontological Social Work 63, 92-113.

Gilbert T and Powell JL (2012) The place that social policy plays in shaping the social context of older people. In Davies M (ed.), Social Work with Adults. Basingstoke, UK: Palgrave Macmillan, pp. 258-272

Gilleard C and Higgs P (2000) Cultures of Ageing: Self, Citizen and the Body. Harlow, UK: Pearson Education.

Giroux H (2008) Against the Terror of Neoliberalism: Beyond the Politics of Greed. Boulder, CO: Paradigm Publishers.

Glendinning C, Challis D, Fernandez J, Jacobs S, Jones K, Knapp M and Wilberforce M (2008) Evaluation of the Individual Budgets Pilot Programme: Final Report. York, UK: Social Policy Research Unit, University of York.

Glynos J, Speed E and West K (2015) Logics of marginalisation in health and social care reform: integration, choice, and provider-blind provision. Critical Social Policy 35, 45-68.

Gramsci A (1971) Selections from the Prison Notebooks. London: Lawrence and Wishart.

Granleese J and Sayer G (2006) Gendered ageism and 'lookism': a triple jeopardy for female academics. Women in Management Review 21, 500-517.

Grassi E and Alayon N (2005) Neoliberalism in Argentina: social policy, welfare and the conditions for the development of social work. In Ferguson I, Lavalette M and Whitmore E (eds), Globalisation, Global Justice and Social Work. Abingdon, UK: Taylor \& Francis, pp. 23-41.

Gray AM and Birrell D (2013) Transforming Adult Social Care: Contemporary Policy and Practice. Bristol, UK: Policy Press.

Gwilym H (2018) Social work, neoliberalism and authoritarianism: an analysis of the policy document. Critical and Radical Social Work 6, 407-413.

Hafford-Letchford P and Formosa M (2016) Mind the gap! An exploration of the role of lifelong learning in promoting co-production and citizenship within social care for older people. European Journal for Research on the Education and Learning of Adults 7, 237-252.

Hall B and Scragg T (2012) Introduction. In Hall B and Scragg T (eds), Social Work with Older People: Approaches to Person-centred Practice. Maidenhead, UK: Open University Press, pp 1-5.

Harris J (2003) The Social Work Business. London: Routledge.

Hayes S and Jandrić P (2014) Who is really in charge of contemporary education? People and technologies in, against and beyond the neoliberal university. Open Review of Educational Research 1, 193-210.

Jameson F (1991) Postmodernism or the Cultural Logic of Late Capitalism. Durham, NC: Duke University Press.

Jones C (1996) Anti-intellectualism and the peculiarities of British social work education. In Parton N (ed.), Social Theory, Social Change and Social Work. London: Routledge, pp. 190-211.

Jones C and Novak T (1999) Poverty, Welfare and the Disciplinary State. London: Routledge.

Jordan B and Drakeford M (2012) Social Work and Social Policy under austerity Basingstoke Palgrave Macmillan.

Kemshall H (2010) Risk rationalities in contemporary social work policy and practice. British Journal of Social Work 40, 1247-1262.

Levitas R (2005) The Inclusive Society? Social Exclusion and New Labour, 2nd Edn. Basingstoke, UK: Palgrave Macmillan.

Lund R (2020) The social organisation of boasting in the neoliberal university. Gender and Education 32, $466-485$.

Lymbery M (2010) A new vision for adult social care? Continuities and change in the care of older people. Critical Social Policy 30, 5-26. 
Lymbery M (2014) Social work and personalisation. British Journal of Social Work 42, 783-792.

Lymbery M and Postle K (2010) Social work in the context of adult social care in England and the implications for social work education. British Journal of Social Work 40, 2502-2522.

Lyotard J-F (1984) The Postmodern Condition: A Report on Knowledge. Minneapolis, MN: University of Minnesota Press.

Marcuse H (1964) One Dimensional Man. London: Ark.

McLaughlin K (2005) From ridicule to institutionalization: anti-oppression, the state and social work. Critical Social Policy 25, 283-305.

Means R (2012) A brave new world of personalized care? Historical perspectives on social care and older people in England. Social Policy and Administration 46, 302-320.

Morely C (2019) Promoting activism and critical social work education. In Webb SA (ed.), The Routledge Handbook of Critical Social Work. London: Routledge, pp. 437-448.

Morely C, MacFarlane S and Ablett P (2017) The neoliberal colonisation of social work education: a critical analysis and practices for resistance. Advances in Social Work and Welfare Education 19, 25-40.

Morely C, Ablett $\mathbf{P}$ and Stenhouse K (2019) Technicist education: paving the way for the social work robots? Critical and Radical Social Work 7, 139-154.

Morrissey J (2015) Regimes of performance: practices of the normalised self in the neoliberal university. British Journal of Sociology of Education 36, 614-634.

Orme J (2012) Evaluation of social work education. In Lishman J (ed.), Social Work Education and Training. London: Jessica Kingsley, pp. 15-35.

Petrie S (2015) 'Commodifying' children: the impact of markets in services for children in the United Kingdom. International Journal of Child, Youth and Family Studies 62, 275-294.

Phillipson C (1982) Capitalism and the Construction of Old Age. London: Macmillan.

Powell J (2012) Social work, power and performativity. China Journal of Social Work 5, 67-79.

Rabiee P (2013) Exploring the relationships between choice and independence: experiences of disabled and older people. British Journal of Social Work 43, 872-888.

Rabiee P, Baxter K and Glenndining C (2016) Supporting choice: support planning, older people and managed personal budgets. Journal of Social Work 16, 453-469.

Rose N and Abi-Rached JM (2013) Neuro: The New Brain Sciences and the Management of Mind. Princeton, NJ: Princeton University Press.

Schram SF (2019) Neoliberal relations of poverty and the welfare state. In Webb SA (ed.), The Routledge Handbook of Critical Social Work. London: Routledge, pp. 15-24.

Scott-Samuel A and Smith KE (2015) Fantasy paradigms of health inequalities: utopian thinking? Social Theory and Health 13, 418-436.

Social Care Institute for Excellence (SCIE) (2012) Personalisation: An Easy Read Guide. Available at https://www.scie.org.uk/personalisation/introduction/rough-guide.

Sothall C, Lonbay SP and Brandon T (2021) Social workers' negotiation of the liminal space between personalisation policy and practice. European Journal of Social Work 24, 238-250.

Tomkow L (2018) The emergence and utilisation of frailty in the United Kingdom: a contemporary biopolitical practice. Ageing \& Society 40, 695-712.

Walker A (2018) Why the UK needs a social policy on ageing. Journal of Social Policy 47, 253-273.

Ward R and Campbell S (2013) An ethics journey: ethical governance of social research with vulnerable adults and the implications for practice. In Carey M and Green L (eds), Practical Social Work Ethics: Complex Dilemmas Within Applied Social Care. Farnham, UK: Ashgate, pp. 151-171.

Webb SA (2006) Social Work in a Risk Society. Basingstoke, UK: Palgrave Macmillan.

West K (2013) "The grip of personalisation in adult social care: between managerial domination and fantasy" Critical Social Policy. 33, 638-657.

Wellcome Trust (2020) What Researchers Think About the Culture They Work In. London: Wellcome Trust.

Woolham J and Benton C (2013) The costs and benefits of personal budgets for older people: evidence from a single local authority. British Journal of Work 43, 1472-1491.

Cite this article: Carey M (2022). The neoliberal university, social work and personalised care for older adults. Ageing \& Society 42, 1964-1978. https://doi.org/10.1017/S0144686X20001919 